\title{
VISUALIZING ROOTS AND ITINERARIES OF INDIAN OCEANIC CREOLISATIONS: Project for a Museum of the Present
}

\author{
Transforming Cultures eJournal, \\ Vol. 3 No 2, November 2008 \\ http://epress.lib.uts.edu.au/journals/TfC
}

\section{Françoise Vergès ${ }^{1}$}

\begin{abstract}
In this paper, I will discuss the methodological problems raised by the museography of a forthcoming museum on Reunion Island, the Maison des civilisations et de l'unité réunionnaise. One of the museum's goals is to retrace visually the itineraries of the processes of creolisation in the Indian Ocean that led to the creation of a singular culture, the Creole indiaoceanic culture. How to visualise the multiple layers of signification at work, the traces and fragments of languages, imaginaries, rituals, practices travelling throughout the ocean, the dynamic of loss, transformation, translation and recreation of forms, rituals, practices in the itineraries of people? I will first present the museum, its context and goals, then suggests ways of "making visual" elements of the Indian Ocean's long history, and finally, discuss the challenges of imagining a museum of the present in the Indian Ocean world.
\end{abstract}

In 2010, a museum and cultural center, Maison des civilizations et de l'unité Réunionaise (MCUR - House of Civilisations and Reunionese Unity), will open on Reunion Island. The project was launched in 1999 by the left majority in the local Regional Council and has been supported by the French government, the European Community and UNESCO. The MCUR building of 9,000 square metres will host spaces for permanent and temporary exhibitions, a video gallery, restaurants, bars, seminar rooms, school rooms, a museum-nursery, two libraries, a theatre and performance spaces. It will be built in a twenty-two hectares park overlooking the ocean and above Saint-Paul - the site of the first permanent settlement on the island. The architectural design was chosen in May 2007 by an international jury. ${ }^{2}$

\footnotetext{
${ }^{1}$ Françoise Vergès lectures at Goldsmiths College, University of London and writes on slavery and creolization. She was awarded the 2006 Françoise Seligmann Foundation Prize Against Racism for her book La Mémoire enchainée. Questions sur l'esclavage (Paris, 2006).

${ }^{2}$ The team is X-TU, a young French team, and their project can be seen at $<w w w . r e g i o n r e u n i o n$.fr $>$, page MCUR, where there is a virtual visit of the project.
} 
In this paper, my aim is to not to review the considerable literature that in recent years has rethought the museum, a literature that has been extremely useful to my work. ${ }^{3}$ Rather, I want to present the scientific choices that engaged the MCUR in the current conversation on museums, visual studies, representation, history, memory and resistance. In my work for the last three years as director of the scientific and cultural team in charge of setting up the cultural program, I had to reflect on the following questions: how does one imagine a museum without a collection of artifacts, of objects? How does one visualise the roots and itineraries of Indian Oceanic creolisations? How does one show the lives of slaves, indentured workers and poor settlers without simply resorting to a description of suffering and poverty? How does one show the materiality of immaterial culture? With Carpanin Mairmoutou, I wrote the scientific and cultural programme which was adopted by the Regional Council in 2005 as the basis for the orientations of the cultural as well as the architectural programs. ${ }^{4}$

In the course of its history Reunionese society has undergone a great many upheavals causing socio-economic turmoil. It has a twofold heritage: one of dehumanisation, contempt, exile, and one of vitality and the will to live and create. The latest upheaval relates to the end of an agricultural and rural world. Faced with new challenges, Reunionese society must offer and pursue a series of reflections based on its cultural assets. They should be repositioned in an approach that takes into consideration social, cultural, economic and political evolutions and transformations on local, national, regional and international levels. Reunion being a French territory, it has to deal with the French resistance to confronting its role in the slave trade and its colonial past. In 2005 , the debate on the current traces of the legacies of slavery and colonialism and the controversies that followed (accusations of anti-republicanism, of nostalgia for the past, of dwelling in victimisation, of "communautarisme" i.e. organisation of groups along ethnic lines) highlighted this resistance. It also demonstrated the existence of a blind

\footnotetext{
${ }^{3}$ Among recent works on the museum, let me cite: Bettina Messias Carbonell, (ed.) Museum Studies, London: Blackwell, 2006; George E. Hein, Learning in the Museum, London: Routledge, 1998; Eilean Hooper-Greenhill, Museums and the Sharing of Knowledge, London: Routledge, 1992; Ivan Karp, Corinne A. Kratz, Lynn Szwaja and Tomas Ybarra-Frausto, (eds) Museum Frictions: Public Culture/Global Transformations, Durham: Duke University Press, 2006; Janet Marstine, (ed.) New Museum Theory and Practice, London, Blackwell, 2006; Richard Sandell and Robert R. Janes, (eds) Museum Management and Marketing, London: Routledge, 2007; Sheila Watson, (ed.) Museums and their Communities, London: Routledge, 2007. This list is far from being exhaustive and does not include the considerable resources on museums found on websites.

${ }^{4}$ The full document (200 pages) is available online (French and English) at $<$ www.regionreunion.fr $>$, page MCUR, where academic references are given.
} 
spot in French thought: the figure of the slave. In textbooks, the slave trade and slavery are barely noted. The academic elite of historians, the mandarins, have disqualified research on these themes and, in public imagination, the "outre-mer" (French territories throughout the world) is totally marginalised if not inexistent. The MCUR project is part and parcel of a movement that is pushing for a revision of the national narrative, claiming that you can be a French citizen and Muslim, and Hindu, and descendant of slave, of colonised peoples, that the debate on democracy and cultural difference is urgent, that the French Republic must rethink its relation with its outre-mer.

The term "museum" was chosen knowingly to describe the MCUR. Even though we dispute the classical idea of the museum, we challenged the idea that "cultural centers" are for the "South" or the French overseas and museums for Europe and treasures. True, the museum has become a controversial institution. Its collections, public or private, were largely realised through looting and dubious acquisitions. ${ }^{5}$ It has been accused of being reserved for an elite and contributing to the emergence of a modernity, with an educative goal through contemplation of the sublime. This European invention of the $18^{\text {th }}$ century was also a travelling institution. Colonial empires built museums in their colonies as part of their civilising mission. In Reunion, two museums were built under the colonial regime: the Museum of Natural History and the Musée Léon Dierx. The former was built to present the fauna and flora of the region along the scale defined by the science of progress and evolution, with "Man" as its apex; the latter host a small part of the collection of Ambroise Vollard, a famous art merchant and collector of early $20^{\text {th }}$ century Paris who was Reunionese. As a "travelling" institution, for new nation states the museum became a symbol of their independence from colonial power. More recently, the museum has been reappropriated by groups who question its statist character and seek to open the institution to new approaches and methodology. ${ }^{6}$ It is within this movement of reappropriation through a series of strategic and tactical moves that the MCUR's project situates itself. James Clifford's concept of contact zones (borrowed from Mary Louise Pratt ${ }^{7}$ ) to portray museums is particularly apt for

\footnotetext{
${ }^{5}$ See for instance, the project $<$ www.brokenmemory.net $>$ on the issues of restitution and the controversy around the opening of the Musée du Quai Branly.

${ }^{6}$ See for instance, the objectives of a group of museums at $<$ www.sitesofconscience.org $>$

${ }^{7}$ Mary-Louise Pratt, Imperial Eyes: Travel Writing and Transculturation, New York: Routledge, 1992. James Clifford, Routes: Travel and Translations in the Late Twentieth Century, Cambridge: Harvard University Press, 1997. The notion of contact zones is from linguistics and the study of creole languages.
} 
describing the MCUR project. Reunion is a contact-zone - its language and culture are those of a contact zone, its location situates the island in a zone of contacts and conflicts between different worlds. Finally, the choice of a museum without a collection inscribes the MCUR in the larger movement of rethinking museums as "sites of frictions" 8 and spaces of exchange.

To begin with, a few facts. Reunion has no pre-colonial past - there was no native population. Its population is entirely the product of the French colonial project in the Indian Ocean; it has been constituted of slaves bought in eastern Africa, Madagascar, the Comoros, and in fewer numbers from India and Yemen, of indentured workers from southern India and China, of Muslim migrants from Gujarat, of migrants from France and Europe. Catholicism co-exists with Hinduism, Sunni Islam, Buddhism, AfroMalagasy rituals and, more recently, Protestant evangelical churches, Boras, Shiite and Karane Islam. It experienced two centuries of slavery, a century of colonialism and indentured work and entered postcolonial democracy as a French department barely sixty years. Currently, it has a 30\% unemployment rate, a failing sugar industry, a high rate of people on welfare and the highest rate of suicide among French regions. The society, predominantly rural sixty years ago, is now strongly urbanised; social welfare coexists with the remnants of colonial privilege (higher salaries for civil servants), a landscape of commercial malls is slowly occupying what used to be sugar cane fields. Yet there is a dynamic cultural scene, a renewed interest in emerging regional expressions and a strong commitment to protect creolised practices and develop strategies of resistance against new forms of cultural assimilation. The project has met considerable support from the population - more than 600 personal objects were donated in one year. The opposition comes from conservatives who either claim that Reunion culture is too poor to deserve a museum or who adopt the current populist antiintellectual discourse. The latter argument, regularly displayed in the two main newspapers, ${ }^{9}$ develops the idea that the project is "intellectual" - i.e. highbrow and incomprehensible for the "people" - and that Reunion society does not "need" a museum on civilisations and creolisation. This anti-intellectual attitude is shared by

\footnotetext{
${ }^{8}$ The notion of "frictions" is developed in Ivan Karp, Corinne A. Kratz, Lynn Szwaja and Tomas YbarraFrausto, (eds) Museum Frictions: Public Culture/Global Transformations, Durham: Duke University Press, 2006.

${ }^{9}$ The two dailies, Journal de l'Ile and Le Quotidien, both owned by Hersant, a media conglomerate, and the communist daily, Témoignages.
} 
some in the local petty bourgeoisie. Usually found among the civil servants, who still benefit from privileges inherited from the colonial past, ${ }^{10}$ the current anti-intellectual discourse rests on paternalism and the reification of Creole culture as a fixed and rigid identity opposed to the "French." Their position is a displacement of the political opposition to Jacobin and neo-colonial France into an ethnicist opposition to anything "French". Thus, cultural movements and debates that have developed in France are ignored. Rather than fighting against the "métropole" - a fictional and fantasised France imported into French overseas territories - they resist "France", a country crossed by new contradictions, of new emergences. They defend a form of nativism marked by insularity and distrust of critical emergences but avid of ethnic goods. Their opposition to the MCUR does not rest on arguments against the foundations and orientations of the project but on their resistance to renewed forms of the vernacular.

The MCUR wishes to demonstrate the power of culture as resistance and the need of culture in a world increasingly dominated by an economic logic that claims to entirely satisfy individuals' needs with goods and consumption. In a society deeply shaped by slavery and colonialism, the MCUR would show the ways in which people had constructed a rich and complex culture and would encourage visitors to reflect on current and future issues facing Reunion and invent their own solutions. The MCUR will not be a museum in the classical sense of the word: its primary purpose is not to collect items and documents and exhibit collections, even if these aspects are included in its objective. It is to be a museum of civilisations, that is, it will show processes and practices, roots and itineraries of people, rituals, spices, plants, ideas and images. It will be a place for exhibitions, discussions, confrontations, interpretations and a place of

\footnotetext{
${ }^{10}$ In all French overseas territories, civil servants receive higher pay than in France for the same post and pay less taxes. These privileges were created during the colonial empire to encourage the departure of civil servants to the colonies. In the 1950s, unions fought for the extension of these privileges to all civil servants. This led to the emergence of a class of individuals whose parents had often been poor and who had suddenly access to goods and social capital. During the $1950 \mathrm{~s}-1960$ s, the society became more diverse and democratized thank to the anti-colonial struggles against the hegemony of a small reactionary, colonial and racist class whose hold on the society lessened. The petty bourgeoisie has benefited from these struggles. As a class, it plays an important role in the French overseas territories. It experiences contradictions. Union and political leaders of the Left and the Right often come from this class; its members were active in the revival of Creole culture. As a reaction against years of hegemonic Frenchness, it has been tempted by nativism and civilisationism, developing an "anti-French" attitude that is more ethnicist than political. The class of wealthy property owners (the "Gros Blancs"), quite active in reactionary politics during the 1950s-1970s, has now invested in the economy. At the bottom, a large part of the population lives with social welfare; $50 \%$ of the poor are under the poverty line. Gustavo Buntinx's notion of "syndrome of marginal occidentality" is useful here. Gustavo Buntinx, "Communities of Sense/Communities of Sentiment: Globalization and the Museum Void in an Extreme Periphery", in Karp et al., (eds) op.cit, p. 223.
} 
proposals, actions, reparations, re-appropriations and restitutions. One of the aims of the MCUR is the critical contextualising and transmission of Reunionese culture. The goal is not to "salvage the heritage" but to offer a "transformative" space where people recognise themselves, their creations and practices, and recognise the contributions of others. $^{11}$

The MCUR proposes to put the past into perspective, starting from the present. It will be the one place envisioning the Reunion territory (human and physical) as something to show, visualise and restitute. It will not be an historical museum but a place where critical, regenerative dynamics will offer the Reunionese a space in which (in the imaginary as well as in concrete exchange) the development of their culture and their society can be performed. The intersecting approach to events promotes a comparative approach putting "worlds of life" into perspective, thus revealing recurrences. In the document Marimoutou and I wrote to present the philosophy of the project, we insisted on calling attention to the contingencies, the accidents of history, challenging the fiction of a linear course presented as inevitably progressive, marked by a modernism defined by Europe, ${ }^{12}$ in which every event can be explained by a structuring causality. We must avoid a causal progression implying an end of history that denies the permanence and creative aspect of conflicts and tensions. We wish to offer means whereby the women and men of Reunion can reappropriate their history and their culture. Symposiums, lectures, seminars, exhibitions, commissioned works, encounters, performances, new communication technologies - the MCUR will use all these tools to offer the Reunionese population a place of perspective and prospective, that is a place where the present informs questions on the past and the future.

The exhibition starts with the Indoceanic world as it was before the island was colonised. If, despite our choice against non-linear narrative, there is a starting point the geological formation of the Indian Ocean - it is to reintroduce another temporality that preceded "human" time and to evoke the autonomy of geological formations.

\footnotetext{
${ }^{11}$ The full document written by Vergés and Marimoutou is available at $<$ www.regionreunion.fr $>$, page: MCUR.

${ }^{12}$ It is clear that we use "Europe" to design a historical and cultural construction, better seen from the colonial world but which has had consequences on the continent itself. Currently, the definition of "Europe" through the debate on the European Constitution has shown that its meaning is far from being exhausted.
} 
Reunion Island is a young formation - barely 3 million years - with a very active volcano, under the threat of cyclones and tsunamis, and its young age impacts on society: the constructible space is a very narrow corridor on the coast, the soil is fragile, heavy rains transform rivers into dangerous floods. "Nature" resists the social desire of total mastery and reminds Reunion inhabitants of its active presence. The "starting point" acts as a reminder of another temporality and of the interaction between insularity, geology and society. We suggest, to start with, the chaos of continental formation, of volcanoes emerging from the ocean and creating islands, thus introducing geological time into human time. Further, the island is situated in an ocean whose rims were inhabited by societies which had known transformations through time, which had created intercontinental and transcontinental routes of commerce and exchange. The civilisations and cultures of the "native" countries will be shown throughout history and the impact of their arrivals upon the island. The physical territory "Reunion" will be put in perspective with the territories created by society (land partitioning, "mountain" and "coast", the kour, the private, the space of ritual and so on). This small island subject to brutal natural events (cyclones, volcanic eruptions, soil in constant formation) and brutal transformations imposed by Man (sugarcane monoculture, the unsustainable exploitation of natural resources, the supremacy of the automobile) must be integrated as an actor in the reflection on its past, present and future. There will be no culture/nature separation constructing nature as a boundless space subject to man's whims and humans as mere objects subject to the liberal management of planners and managers. The physical territory of the island will be staged in an ocean whose rims have been inhabited by peoples endowed with complex and rich social and cultural organisations. The encompassing category "African slave", "Hindu indentured worker", "French colonist", will be questioned and individuality restored: which gender, age, language, social status, religious beliefs? The visitor will be invited to grasp the crossed contributions from the beginning of colonisation right through Reunionese history up to today.

The organisation of sequences aims to suggest a reading which relates events in the history of the Indian Ocean to events in Reunion. Within each sequence, the local translation of social and cultural practices are highlighted. This chronology wishes to be constructive and creative by providing the visitor with an autonomous interpretative space. The visitor is invited to grasp the long history of the Indian Ocean as a cultural 
space of encounters, exchanges and conflicts. History did not start with European colonisation and the present cartography of routes can be read alongside older cartographies.

The visitor is further invited to discern the crossings and interactions between the various contributions of incoming groups and to understand the creolisation processes under way since the beginning of colonisation. The exhibition presents the movement between diversity and unity, between the world and Reunion, Reunion and the world. The transformations of the "Reunion" territory - land distribution, partitioning between "small" territories (mountain/coast, Upper/Lower, East/West, North/South, private/public, sacred/secular, female/male) - is broached as the exhibition deals with the past, the present and the future of the territory. How was it inhabited? By whom? Why? How will it be inhabited?

The permanent exhibition is based on the crossed interpretation of "histories". In a region where six worlds have met - African, Malagasy, Hindu, Muslim, Chinese, European - not counting the myriad of contributions from islands such as Zanzibar and the Comoros, and in a situation where these worlds have merged on a small territory, it is impossible to focus on a single history. The MCUR must present the history of each world, the interaction between the worlds and the processes of creolisation on Reunion. The interaction between these histories, between oral and written history, between different narratives (of women, of the powerful, of the oppressed) requires understanding history as a crossed interpretation of events where sociology, anthropology, philosophy, philosophy of religions, geography, knowledge of fauna and flora, and art history all have a role to play. History alone cannot explain the polysemy of a moment that encompasses the analysis of the actors' perceptions, representations, tales and myths and seeks to explain and understand the actors' role in this particular event. The singular and original Reunionese point of view on world events is shown through texts and visual archives.

The concept of "several exhibitions in one" implies creating exhibition areas with several distinct points of view as well as connections facilitating the circulation from one space to the other. The permanent exhibition rests on two "representations": 
- The history and civilisations of the six worlds which contributed to Reunion's culture and society (India, China, the Muslim world, Africa, France, Europe, and the islands of the Indian Ocean),

- History, cultures and creolisation in Reunion.

The section on the history and civilisations of the countries from which inhabitants came and are still coming (thereafter "native countries") presents the history and cultures in these countries prior to the immigrations towards Reunion, at the time of these movements of populations and up to the present time. The name "native countries" covers all the countries from which the components of the Reunionese population came at one time or another: Madagascar, India, Mozambique, Tanzania, France, China, Malaysia, Vietnam, Comores, Mauritius. In this section, the MCUR underscores events that had effects on Reunion, even if these repercussions are not obvious at first sight. Hence, the poverty of the French peasantry in the seventeenth century partly explains the arrival of the first colonisers on the island. The abolitionist movements in the United States and England, as well as the abolition in Mauritius, were not without consequences for the abolition of slavery in the French colonies. The Haitian revolution had an influence on the slave system in Reunion and its abolition. The colonisation of China by European empires and the poverty of the Chinese peasantry led to the organisation of emigration (indentured labour) to the Indian Ocean.

The section on the history, cultures and creolisation of Reunion gives visibility to the events of the island. We suggest another chronology than the one experienced either as a mirror reflection of the history of mainland France (Revolution, Empire, Republic) or as one that would be solely organised around international economic upheavals.

Six "across" dates have been chosen through which the state of each of the six worlds at that moment will be put in perspective: $5^{\text {th }}$ to $16^{\text {th }}$ century, the golden age of Indian Ocean commerce; 1498-1725, the Europeans enter the Indian Ocean and slavery is instituted in Reunion; 1725-1848, masters and slaves, colonial empires and the abolition of slavery in Reunion (20 ${ }^{\text {th }}$ December 1848); 1848-1920, the Age of Empire, of race and science and, in Reunion, the massive arrival of indentured workers from south India and south China as well as the first emergence of unions and civil society ; 1920-1946, the end of colonial status in Reunion; 2000, the end of colonial empires, the birth of new 
states, new cartographies of power, exchange and conflicts, and in Reunion, the end of rural society, mass education modernisation; and finally, current mutations. The interaction between the Indian Oeanic space and Reunion's own temporality seeks to suggest another vision, to shift the gaze (making the island of Reunion its center) and aims at being open and dynamic (to take into account future discoveries). By approaching creolisation and Reunionese unity from several angles, this dimension of the exhibition will show the originality of "Reunionese ways of being in the world" and open up discussion on contemporary issues.

\section{Creolisation}

Reunionese society is not the product of enclosed categories, as in a colonist from Picardy + a slave from Mozambique + an Indian engagé + a Muslim tradesman + a Chinese shopkeeper $=$ a Reunionese. Instead the content is conceived as what each group brought to the others, how what each group brought altered what existed already, opening a new dimension in the local worldview, new practices, new culinary tastes, new vocabulary, new beliefs. The notion of creolisation is more pertinent (and Reunionisation could be the local form of creolisation, but we wish to avoid an excessive territorialisation of a term). Jean Benoist, a renowned scholar of Creole societies, has argued that there is no creolisation without contention, tension between marked contrasts and unity, contrasts shaped by unity and unity shaped by contrasts and both, unity and contrasts, produced by the same economic and political structure. The conflictual, unequal character of the creolisation process is fundamental for our conception.

On arriving at Reunion, each group underwent a creolisation process, that is, its members were led to give up their beliefs, traditions and practices but also to preserve some aspects of these beliefs, traditions and practices, while borrowing from others. Yet, the process of creolisation started, we argue, from the moment of capture, in the barracks where slaves awaited the ship, and in the ship itself. It started when the Malagasy captive left his country and had to brutally reinvent a world. It started when the young woman left her Tamil village or city and underwent Kalapani, the forbidden crossing. It started for the Chinese during his migratory route from Canton to Mauritius to Reunion. The itinerary of creolisation is a circuitous route of stops and goes, of settlements and movements through the Indian Ocean world. In Reunion, we have to 
constantly hold together six worlds: the African, Chinese, European, Muslim and insular, the islands that contributed to the world of exchanges and encounters, Madagascar, Comoros, Zanzibar. Creolisation is that simultaneous dynamic of loss and preservation of beliefs and practices (necessarily altered). In this way, each new group (of slaves, indentured workers, immigrants) underwent a process of creolisation through those already settled who passed on to them (sometimes violently) methods of survival, but those already settled received from the newcomers traces of forgotten traditions and beliefs. Groups brought with them spices, rituals, myths, songs, music, recipes, which they adapted and which were adopted through a continuous process of creolisation. Creolisation is thus understood as a dynamic between loss and loan where the unity of differences does not cancel differences nor require their assimilation, but where unity is altered by new differences. There is a creole ethos, an ethos of creolisation that strives to preserve the balance between unity and diversity in the name of the common past of violence, deportation and exile. It is an ethics of translation, the space where cultural practices confront one another and borrow from one another to create a new space in which the individual negotiates its identity.

The following are two examples of the visualisation of creolised practices and beliefs:

- "shemin la vi, shemin la mor": birth, christening and other birth rituals, childhood, adolescence, marriage, death rituals and practices connected with these different ages of life draw attention to a creolisation of these practices.

- "Indoceanities": routes of exchanges, contacts and conflicts in the Indian Ocean restoring the cultural space the island belongs to and the routes and itineraries of the individuals and groups that populated it.

Continuous and fragile, the processes of Indian Oceanic creolisation on the island of Reunion exemplify the relations of negotiation and confrontation at work in a society among groups that are subjected to a deeply unequal and racially divided system. Creolisation is not a harmonious process; it is the community in being at work. Our conception of creolisation departs from Edouard Glissant's ${ }^{13}$ who sees creolisation as an inevitable process. When cultures meet, the result is not always creolisation. It might be apartheid, segregation, indifferent coexistence. Furthermore, creolisation occurs in very diverse situations and the conditions of its emergence deserve attention. In Reunion and

\footnotetext{
${ }^{13}$ Edoaud Glissant, Poétique de la relation, Paris: Gallimard,
} 
in Mauritius, we noted that the population of slaves and indentured labourers was predominantly male ( $2 / 3$ men for $1 / 3$ women), as in the Caribbean, but this fact is not analysed. In Reunion, in big plantations, the gender ratio could be 1000 men for 30 women. Equilibrium between the sexes only occurred at the beginning of the $20^{\text {th }}$ century, which implies that men played an important role in the process of creolisation. Malagasy was the lingua franca throughout the Indian Ocean slave colonies for many years due to the importance of Malagasy slaves (unlike the Caribbean). Finally, the contributions of Muslim, Hindu, and Chinese cultures are greater in Indian Oceanic Creole societies. There is not a unique model of creolisation but there is a process of creolisation.

The fragility of creolisation - faced with dominant cultural expressions, with the cultural products of essentially profit-seeking multinational corporations - must be recognised and viewed in the context of liberal globalisation, the rise of murderous identities and retreat of reconstructed purified identities. It is also under attack from a local petty bourgeoisie which has turned to "civilisationism", that is claiming roots with regional powers to counter the expression of a French dominant culture. Rather than insisting on creolisation, it invokes the "great" civilisations from which their ancestors came to counter a European centered narrative. This is clearest among Malbars (the vernacular name given to Indian indentured workers) who recast themselves as Tamils and seek, with the help of priests and architects from India, to purify creolised Hinduism. Vernacular temples are destroyed to give place to gaudy Bollywood style temples, vegetarianism is preached and the sacrifice of animals frowned upon if not forbidden. The aim is to cleanse creolised Hinduism, which welcomed other gods and goddesses from Madagascar and Africa and accommodated some Muslim practices. Priest are brought from India to import "true" Hindu practices to Hindus thought to have "lost" the purity of their ancestors' beliefs. Cultural practices lose their history and their connection with popular resistance, they are abstracted from their practitioners. Creole culture becomes another tourist attraction. For years already, Reunion has been sold as the island where, in one day, the tourist can encounter different cultures without hearing once about slavery and colonialism. 


\section{Routes, paths and itineraries}

In the permanent exhibition, the first modality of mediation is metonymical of the constitution of the Reunionese people and culture. No ancestor is autochthonous, we claimed. Thus the genealogical relationship of each Reunionese passes through an itinerary, a movement, a displacement. In fact, except for one species of fruit tree (pomme latanier), everything has been brought through successive migratory movements: ginger, turmeric, mango, litchis, pineapple, chili, recipes, rituals, practices, gods and goddesses.

The path is the metaphor of exile that crosses routes of trade and empire but is symbolically different. It evokes the trails of the maroons and their resistance, the appropriation of the territory by fishermen, farmhands, market women, vagabonds. These paths and trails outline another cartography, another archive of the island. The path draws the ancestor's course: the one leading from him to us and the one leading us back to him.

The display of the itineraries of persons, objects, rites, culinary practices, recipes, sounds, allows the visitor to follow the routes and itineraries of Reunionese culture. They are a mise en scène of its dynamism, its capacity to absorb, its fluidity. These itineraries show the routes of multiple levels of culture. Nothing is fossilised, nothing is pure and yet continuity emerges. "Reality is polymorphic, formed by multiple identities and constant metamorphoses," "it is at the heart of metamorphosis and precarity that the true continuity of things lies" ${ }^{, 23}$. From the place of origin, whence the ancestor came to the world he contributed to build and bequeathed to us, the itinerary brings back a life. The richness of a world is restored. The neutral category ("slave", "engagé", "Kafr", "Malabar", "Muslim"), meaning one that negates singularity (how old? what gender? what place of origin? what city, country, coast?), fades away before the combined individual and collective experience that shaped the Reunionese world.

For instance:

- The itinerary of an object - furniture, drum, pestle, rice-cooker - that is associated with a time-space. Where does it come from? How did the item get to

\footnotetext{
${ }^{23}$ Serge Gruzinski, La Pensée métisse, Paris: Fayard, 1999, p. 22.
} 
Reunion? How was it integrated in the home, in the public space? The everyday object - TV, radio - is presented in its context but the object is not shown as "passive". We can see how it transformed users' lives (what was the impact of TV serials or of radio on the way male/female relations and social relations were perceived?) and how people transform it. These displays of itineraries reintroduce the everyday object into culture. There is no separation between highbrow and lowbrow culture.

- The itinerary of a rite -servis kafr, walking on fire. Where does it come from? How did it get to Reunion? How was it transformed? How was it integrated in the home, the public space? How has it evolved?

- The itinerary of a person: a woman or a man whose trajectory the visitor follows from the native world with information on the social organisation, the culture, the economy of that place, up to when she settled in Reunion. How does the trajectory transform the individual? How does she reinvent herself? How is her identity, her life, transformed by the colonial system? These singular courses show the complexity and diversity of contributions. They also bring back to life the forgotten stories of hundreds of thousands of persons who came to this island.

- The itinerary of a spice, a medicinal plant, a vegetable, something having to do with cuisine and health. Where did saffron come from? How was it integrated in the cuisine? Brèdes, cod, rice, manioc? Where did knowledge about such and such a medicinal plant come from? The itineraries of plants and spices draw maps of trade and exchange (see the example of the Trade Wall of The Museum of Sydney that places Australia in the long time span of Indian Oceanic history before and during the empire).

\section{Objects, memories, installations}

Visualising the roots and itineraries of creolisation demands that we think about immaterial culture, the voices of the voiceless, the objects of those who left no objects. The absence of material vernacular objects from the past and the presence of a rich immaterial creolised culture required a politics of visualisation that would represent the exchanges and borrowings between practices. For instance, the Nargoulan is a mast found in vernacular Hindu temples (koilou) on top of which there is a flag with the Muslim crescent. Though hegemonic narrative has transformed all indentured workers 
from south India into Hindus, it has been proven that there were Muslims among the migrants. As the convention between imperial England and imperial France demanded that Hindus could practice their religion on the sugar plantations of French colonies, indentured workers built temples in which, unbeknownst to the colonial power, they incorporated a space and a symbol for the Muslims. This installation of symbols, signs and objects is often the aesthetics of Reunion creolisation. Gardens, for instance, often host altars to the different ancestors, real or imagined. Vernacular installations suggest a visual mediation for the museum.

Objects that would testify to the lives of slaves, poor settlers or indentured workers do not exist. Vernacular objects are rare and do not go back prior to 1920. The lives of women are even more absent from material culture. When on $20^{\text {th }}$ December 1848,60 000 slaves (out of 100,000 inhabitants) became free, nobody sought to collect their memories. Not one. The iron of chains was recycled; the homes of slaves destroyed. This also happened to poor "whites" and indentured workers. Neither the colonial power nor the local elite sought to preserve and protect the vernacular of the poor. Creole language, rituals and practices constitute the immaterial archive of these lives. Where buildings, temples or houses remained, they have in recent years been under threat from a policy of modernisation. The need for schools, parking stations, commercial malls, housing and roads has taken precedence over the preservation of vernacular material culture. Plantation houses were more protected. In recent years, many have been renovated, with public funds. However slaves and indentured workers lived on private property whose owners have neglected to preserve material remnants of the past or have destroyed them. The French government has not conducted important archaeological programs, nor has it systematically intervened with private owners to stop the destruction of temples and houses. ${ }^{14}$ In fact, there is still no wide agreement on what should be preserved, transformed or destroyed. In summary, the MCUR must work from traces, fragments, oral memories and evocations. Rather than organising the permanent exhibition around objects, installations of sounds, fixed and moving images, oral testimonies, contemporary art, fragments of objects and reproductions of archives and documents will construct relational connections between signs. The only way an observer can account for the complexity of a society's cultural practices is by showing

\footnotetext{
${ }^{14}$ In February 2007, a Hindu temple dating from the $19^{\text {th }}$ century, inestimable for its paintings, was destroyed by a private owner. The government was warned by associations but did not intervene.
} 
the constantly hybrid character of signs. For Reunion we must attempt this approach and create an index of representations.

\section{A postcolonial museum of the present}

The MCUR's objective is to be a postcolonial museum of the present, that is a museum as a social and cultural space where legacies of the past are analysed and interpreted so that new solutions may be invented to transform the present and invent the future. The scientific and cultural team is currently consists of twenty people. Its mission is to work with architects and museographers, and with the population, to develop a series of activities and to prepare the opening of the MCUR. A dozen, young Reunionese have been selected to train as cultural mediators. They first participated in a campaign throughout the island whose goal was to inform people about the project and to invite them to contribute through testimonies and the donation of objects for the future installations. They follow seminars on post-colonial theory and are trained by professionals in cultural mediation. In 2004, we created an honorary title, Zarboutan Nout Kiltir, inspired by the "living treasures" of Japan. The title honors annually the contribution of women and men in the preservation, transmission and creation of vernacular culture. We also work with schools. Teachers attend voluntary seminars where they learn about the project and its objectives and programs are also done with school children. At the end of the school year, children show their realisations (music, dance, theater, paintings) to the public at a show organised by the MCUR. There is a monthly conference with a scholar, either on the history and culture of one of the six worlds or on current issues (climate changes, demography, geo-political conflicts, architecture).

The MCUR wishes to contribute to the emergence of a renewed terrain of critical thinking in a post-colonial society, a French and European region located on an AfricanAsian axis, in the Indian Ocean, a space of convergences and exchanges, of conflict and encounters. On the "margins" of Africa, in the "extreme periphery" of Europe, La Reunion constructs for its $21^{\text {st }}$ century a postcolonial museum of the living present.

\section{Bibliography}

Carbonell, Bettina Messias (ed.) Museum Studies (London: Blackwell, 2006). 
Clifford, James Routes: Travel and Translations in the Late Twentieth Century (Cambridge: Harvard University Press, 1997).

Glissant, Edouard Poétique de la relation (Paris: Gallimard, 1990).

Gruzinski, Serge La Pensée métisse (Paris: Fayard, 1999).

Hein, George E. Learning in the Museum (London: Routledge, 1998).

Hooper-Greenhill, Eilean Museums and the Sharing of Knowledge (London: Routledge, 1992).

Karp, Ivan, Kratz, Corinne A., Szwaja, Lynn and Ybarra-Frausto, Tomas (eds) Museum Frictions: Public Culture/Global Transformations (Durham: Duke University Press, 2006).

Marstine, Janet (ed.) New Museum Theory and Practice (London: Blackwell, 2006).

Pratt, Mary-Louise Imperial Eyes: Travel Writing and Transculturation (New York: Routledge, 1992).

Sandell, Richard and Janes, Robert R. (eds) Museum Management and Marketing (London: Routledge, 2007).

Watson, Sheila (ed.) Museums and their Communities (London: Routledge, 2007).

\section{Internet Sources of Information:}

$<$ www.brokenmemory.net>

Conseil Régional de la Réunion, available online: <www.regionreunion.fr $>$

International Coalition of Sites of Conscience, available online:

$<$ www.sitesofconscience.org $>$ 